\title{
The effect of surveillance intensity on long-term survival following curative surgical treatment for solid cancers:
}

A systematic review and meta-analysis

Giglio, Victoria ${ }^{1}$, Madden, $\mathrm{Kim}^{1}$, Schneider, Patricia ${ }^{1}$, Lin, Bill ${ }^{1}$, Multani, Iqbal ${ }^{2}$, Baldawi, Hassan ${ }^{1}$, Thornley, Patrick ${ }^{1}$, Naji, Leen ${ }^{1}$, Levin, Marc ${ }^{3}$, Wang, Peiyao ${ }^{1}$, Bozzo, Anthony ${ }^{1}$, Ghert, Michelle $^{4}$

\section{Author Affiliations:}

1. Division of Orthopaedic Surgery, Department of Surgery, McMaster University, 1200 Main Street West, 4E15, Hamilton, ON, L8N 3Z5, Canada.

2. Royal North Shore Hospital, Reserve Rd, St Leonards, Sydney, New South Wales, 2065, Australia

3. Michael DeGroote School of Medicine, McMaster University, 1200 Main Street West, 4E15, Hamilton, ON, L8N 3Z5, Canada.

4. Hamilton Health Sciences, Juravinski Hospital and Cancer Centre, 711 Concession Street, Level B3 Surgical Offices, Hamilton, ON, L8V 1C3, Canada 


\begin{abstract}
Background

The number of cancer survivors continues to increase due to advancements in cancer treatment. Consequently, the number of patients requiring post-operative surveillance protocols have increased, highlighting the need to develop post-operative surveillance protocols that increase survival benefit while remaining both cost- and resource-effective.
\end{abstract}

\title{
Methods
}

We carried out a comprehensive and systematic literature search of medical databases for randomized controlled trials (RCTs) in which patients with solid tumors 18 years of age or older that had undergone surgical resection with curative intent and had no metastatic disease at presentation, were randomized to different surveillance regimens to assess the effect on overall survival (OS). According to a priori definitions, surveillance programs were classified as (1) biological test, (2) frequency, (3) imaging, or (4) practitioner type. We carried out a pooled effect size estimate on risk ratios (RR) to evaluate the effect of more intensive versus less intensive surveillance strategies in each of the surveillance program categories on overall survival (OS).

\section{Results}

Our search yielded a total of 32,216 articles for review. Following all screening stages, 18 distinct RCTs were included in the systematic review. Most studies evaluated colorectal cancer patients $(11 / 18,[61 \%])$. Twenty-one comparisons from the 18 trials were included in the meta-analysis, with no significant difference in OS for any of the more intensive surveillance program categories analysed. One comparison evaluated biological test interventions and therefore, a meta-analysis was not conducted. Six comparisons were classified as frequency interventions with a combined RR of 0.96 (95\% CI: 0.79-1.16). Eleven comparisons were classified as imaging interventions with a combined RR of 0.99 (95\% CI: 0.91-1.08). Two comparisons were classified as practitioner type interventions with a combined RR of 1.106 (95\% CI: 0.64-1.91). No difference in OS was observed in any of the cancer type subgroup analyses.

\section{Conclusion}


The cost of cancer care is steadily rising due to the growing number of cancer survivors, leading to questions in the ability of healthcare systems to meet the needs of patients. This study demonstrated that there is currently no evidence to support any kind of more intensive surveillance in solid cancers after treatment when considering OS as the primary outcome. However, due to persistent clinical equipoise and advancements in surveillance options, further large RCTs are required to evaluate the most optimal surveillance protocol for individual cancer types.

\section{Introduction}

Surgical intervention is the primary treatment for an attempt at cure for many types of solid tumors including breast, colorectal, testicular and non-small cell lung cancers ${ }^{1}$. Following surgery, the risk of local recurrence or metastases remains a concern for patients and clinicians. Therefore, the use of post-operative surveillance protocols, which include follow-up appointments, biochemical tests and surveillance imaging in likely areas of recurrence or metastases, have become the standard of care in the management of solid cancers $^{2}$. However, the development of post-operative surveillance protocols that increase survival benefit while being both cost- and resource-effective remains challenging ${ }^{2}$.

Clinicians are presented with multiple surveillance possibilities in the post-operative period due to recent advancements in available imaging modalities and molecular diagnostic tests to detect malignant disease. However, adverse effects of surveillance programs that make use of more intensive imaging modalities and / or more frequent follow-up visits are noteworthy. Patients have expressed concern over harmful levels of energy and radiation exposure used in advanced imaging techniques, as well as the direct and indirect costs associated with more frequent follow-up visits ${ }^{2-}$ ${ }^{6}$. Direct costs to the healthcare system for more intensive surveillance programs are also notable, ranging from $\$ 20,000$ to $\$ 30,000$ USD per patient for an intensive five-year post-operative cancer surveillance protocol that often have little to no clinic benefit compared to minimal surveillance protocols $^{7-11}$. Moreover, The American Society of Clinical Oncology recommends not to perform additional surveillance testing or imaging in asymptomatic patients if available evidence suggests these tests do not improve outcomes ${ }^{12}$. The number of cancer survivors continues to increase, with an estimated 16.9 million individuals as of January 2019 in the United States alone. This figure is expected to grow to an estimated 22.1 million individuals as of 2030, resulting in an even greater 
emphasis on the development of evidence-based post-operative treatment guidelines that balance cost efficacy and patient quality of life ${ }^{13}$.

The National Comprehensive Cancer Network (NCCN) develops and updates guidelines as well as provides recommendations on best-practice treatment and surveillance for various cancers based on the best available evidence, with large randomized controlled trials (RCTs) sought as the highest-quality evidence ${ }^{14,15}$. In order to inform future guidelines, we carried out a systematic review and meta-analysis of studies in which cancer patients were randomized to different biological test surveillance, frequency surveillance, imaging surveillance or practitioner type surveillance regimens to determine if less intensive post-operative surveillance effects overall survival (OS) in this patient population as a whole, with a focus on different cancer types when possible.

\section{Methods}

This systematic review adheres to and is reported according to the 2009 Preferred Reporting Items for Systematic Reviews and Meta-Analyses (PRISMA) guidelines. The review protocol was submitted for registration on the International Prospective Register of Systematic Reviews (PROSPERO) (ID:150689).

\section{Eligibility Criteria}

The study population included solid cancer patients, 18 years of age of older that had previously undergone surgical resection of their tumors and had no metastatic disease at presentation. All oncology subspecialties were eligible. Included studies were RCTs, including cluster RCTs. All RCTs that evaluated the efficacy of a post-operative surveillance regimen were eligible for inclusion. Specifically, we included studies that investigated different follow-up frequencies (e.g., post-operative clinic follow-up visits every three months vs. every six months), different imaging or laboratory diagnostic techniques (e.g., post-operative Computed tomography (CT) scans vs. plain radiographs), or different practitioner visit types (e.g., post-operative nurse visits vs. specialist visits). Studies were eligible for inclusion if they assessed overall survival as one of their primary or secondary outcomes. Only published journal articles in the English language were considered, with no lower limit on the study publication year. 


\section{Information Sources}

A comprehensive and systematic literature search of MEDLINE (OVID Interface, 1946 to present), EMBASE (OVID interface 1974 to present), and CENTRAL databases was conducted on 21 August 2019. Additionally, reference lists of included articles were scanned by reviewers for potentially eligible titles.

\section{Search}

In conjunction with a health research methodologist (KM), the search strategy was developed uniquely for each medical database by combining exploded medical indexing terms $\left(\mathrm{MeSH}{ }^{\circledR}\right.$ terms for MEDLINE and CENTRAL, EMTree ${ }^{\circledR}$ terms for EMBASE) and keywords using Boolean operators 'OR' and 'AND'. The search was limited to journal articles published in the English language and included terms to filter for RCTs as developed by the Scottish Intercollegiate Guidelines Network ${ }^{16}$. The full search strategy can be found in Supplementary Materials Appendix I.

\section{Study Selection}

Duplicate removal was performed in two rounds. The first round of duplicate removal was conducted manually on RefWorks by one author (BL) after extracting a listing of articles from each medical database and uploading them on to the RefWorks System. After the completion of the first round of duplicate removal, remaining articles were uploaded onto the DistillerSR online software (www.evidencepartners.com) to create a study database. A second round of duplicate removal was conducted using DistillerSR's duplicate identification feature, and two authors (BL and VG) independently audited the integrity of this feature by verifying that identified articles were in fact duplicates prior to deletion. Author pairs (BL and PS / BL and HB / BL and PT / LN and $\mathrm{AB} / \mathrm{ML}$ and PT / VG and PS / VG and IM / PS and PW) independently screened titles and abstracts identified in the literature search to determine if the articles should be considered for inclusion. The following inclusion questions were used: (1) Does this article describe a RCT?, (2) Do the participants of this trial have a solid tumor?, (3) Was the cancer treated with surgery with curative intent prior to inclusion in the RCT?, (4) Does the RCT assess different post-operative follow-up regimens?, (5) Is there any other reason for exclusion of the study?. The full texts of 
included abstracts were then reviewed in duplicate (VG and IM / PS and PW) for inclusion using the aforementioned inclusion questions, in addition to the following questions: (6) Were the participants of this trial non-metastatic at the time of inclusion in the RCT, and (7) Is overall survival evaluated as a primary or secondary outcome?. These two inclusion questions were added at the full-text screening stage as this information was found to only be available in the full text of papers when pilot testing eligibility questions. All discrepancies were resolved by consensus with the senior author (MG).

\section{Data Collection Process and Data Items}

Data was extracted in duplicate (VG and IM) using study-specific data collection forms uploaded to DistillerSR. Additional information on RCTs was obtained from protocols or dissertations as required. Authors were contacted on multiple occasions for any missing data.

Data extraction forms were pilot tested on two randomly selected full texts to ensure that reviewers extracted data consistently and to ensure the forms were unambiguous and free from errors. Study Characteristics, Risk of Bias, and Statistical Reporting data were collected on independent data extraction forms (Supplementary Materials - Appendix II). Statistical information including event rates and related effect measures for OS were extracted from each article. Event rates were calculated from OS percentages when raw results were not reported in the article and could not be obtained from the authors. The most recently published article was used for OS results when updated OS results were published for the same trial.

Studies were classified into categories in duplicate (VG and IM) based on the type of interventions assessed. If a trial was factorial in design, each comparison within the trial was categorized independently into an intervention category. Due to the large variation in surveillance programs, categories were predefined as per below:

1. Biological tests - any study that evaluates more intensive versus less intensive or sensitive (including a reduced number or none at all) laboratory tests.

2. Frequency - any study that evaluates more frequent versus less frequent (including a reduced number or none at all) clinic visits. 
3. Imaging - any study that evaluates more intensive versus less intensive (including a reduced number or none at all) imaging modalities.

4. Practitioner type - any study that evaluates specialist (medical oncology or surgeon)led versus primary care physician or nurse practitioner-led.

Interventions within each RCT were then categorized as either the more intensive- or less intensive-group (control group). Due to the wide range of intervention types, we defined more intensive surveillance as the most comprehensive treatment of the treatment groups in any given trial (i.e., the treatment that is: more frequent, contains more invasive surveillance component(s) or is specialist-led). Any disagreements were reconciled with the senior author (MG).

\section{Risk of Bias in Individual Studies and Across Studies}

Author pairs (VG and IM) individually assessed included studies on the quality of trial and risk of bias using the Risk of Bias form. This form follows the Cochrane Collaboration's Risk of Bias tool, which reports on the risk of bias as opposed to focusing on the quality of reporting ${ }^{17}$. Any disagreements were reconciled with the senior author (MG). A funnel plot was constructed and visually assessed for asymmetry for publication bias. The overall quality of evidence for each intervention category on OS is presented in the summary of findings using judgement from the five Grading of Recommendations Assessment, Development and Evaluation (GRADE) factors: (1) limitations in study design or execution, (2) inconsistency of results, (3) indirectness of evidence, (4) imprecision and, (5) publication bias. All factors were considered in providing a final grade to the quality of evidence of any of, high, moderate, low or very low quality as described in the GRADE handbook ${ }^{18}$. A justification for each GRADE rating is provided by the review authors.

\section{Summary Measures and Synthesis of Results}

Descriptive statistics, percentages and means or medians were used to summarize categorical and continuous variables, respectively.

OS was the primary endpoint for this systematic review and meta-analysis. Effect measures (relative risks, odds ratios or hazard ratios) along with confidence intervals and hypothesis testing are presented for study characteristics whenever possible. When trials presented more than one hypothesis test, we selected the most adjusted test to report. 


\section{Pooled Analysis}

We included all studies with poolable data in the meta-analysis. We chose to report meta-analysis findings as RRs with 95\% CIs because RRs are most commonly reported in trials evaluating overall survival and they are easily interpreted by clinicians ${ }^{19}$. We evaluated each comparison in a factorial trial independently in their previously categorized intervention type category. We used random effects models in every analysis due to the hypothesized heterogeneity between studies (e.g. differences in cancer types, patient characteristics and details of intervention protocols). We assessed heterogeneity with the $\mathrm{I}^{2}$ statistic. $\mathrm{I}^{2}$ describes the percentage of variation across studies that is due to heterogeneity. Pooled analyses are presented as forest plots with RR and 95\% confidence intervals.

We conducted subgroup analyses on OS to calculate a pooled effect estimate based on a priori categories of cancer types. If we could not conduct an analysis due to a lack of data, conclusions for each intervention category were summarized descriptively based on reported outcomes as: (1) less intense surveillance performed better than comparators for survival outcomes, (2) less intense surveillance performed worse than comparators for survival outcomes, or (3) no difference in survival outcomes. No additional analyses were conducted. P-values less than 0.05 were considered statistically significant. All analyses were performed with Review Manager version $5.3^{21}$.

\section{Results}

\section{Study Selection}

Our search of databases yielded 32,197 potentially eligible studies titles, with an additional 19 records identified through reference list screening. Following duplicate removal, 25,825 titles remained for screening. 25,772 studies were excluded following title and abstract screening due to not being RCTs, patients not having sarcoma or carcinoma, patients not treated with surgery, or the RCT not assessing different post-operative follow-up regimens. Fifty-three articles remained for full text screening. Thirty-two articles were excluded at this final stage, resulting in 21 articles reporting on 18 distinct trials being included in the systematic review ${ }^{22-42}$. Two RCTs published extended follow-up time frame results ${ }^{28,34}$, and one RCT published an additional cost-analysis based on the trial results, while also addressing overall survival results ${ }^{24}$. Other reasons for 
exclusion included the article being a conference abstract or preliminary results from a trial in which OS was not presented. Study selection is presented in Figure 1.

\section{Study Characteristics}

The 18 RCTs comprised a total of 9,020 participants from 11 different countries. Most trials' coordinating centres or initiating sites were based in Europe, 15/18 (83\% $)^{22-25,28-32,35-37,38-40}$ with the remaining sites in China $(1 / 18,[6 \%])^{41}$, India $(1 / 18,[6 \%])^{34}$, and Australia $(2 / 18,[11 \%])^{38,42}$. Fourteen of the 18 RCTs $(78 \%)$ were published prior to $2010^{22-25,28,30-31,35,37-39,41-42}$. The most common type of cancer studied was colorectal cancer, $(11 / 18[61 \%])^{23,28,30-32,35.36,38-41}$, and one RCT included patients with only colon cancer and not rectal cancer due to slightly different followup programs between the two cancers ${ }^{42}$. The remaining types of cancers studied included breast cancer $(4 / 17[22 \%])^{22,24-25,37}$, lung cancer $(1 / 18[6 \%])^{29}$, and bone and soft-tissue sarcomas $(1 / 18$ $[6 \%]^{34}$. Fifteen of the 18 RCTs were parallel group trials, $(83 \%)$, with the other three of factorial design $25,31,34$. Study characteristics of included studies are show in Table $\mathbf{1 .}$

Due to multiple comparisons in factorial trials and one trial using different follow-up protocols for high-risk and low-risk patients ${ }^{38}$, a total of 23 comparisons of intervention strategies were assessed in the 18 included trials. There was a high-level of variation in the intervention strategies used in each trial, with no two trials comparing identical intervention strategies. One comparison (4\%) was classified as a biological test intervention, eight comparisons (35\%) were classified as frequency interventions, 12 comparisons (52\%) were classified as imaging interventions, and the remaining two comparisons (9\%) were classified as practitioner type interventions. Often, comparisons in the imaging category evaluated the presence of an imaging test versus not using that imaging modality at all in the follow-up program.

\section{Risk of Bias in Included Studies}

Blinding of patients and research personnel was not possible due to the nature of the interventions, therefore all studies have a high risk of performance bias. Many trials did not report, or it was unclear, if the assessment of outcomes was blinded and if results were selectively reported in trials. This was due to most trials not publishing a protocol, possibly a consequence of the older publication dates of included trials. Overall risk and quality assessment of the trials are presented 
in Table 2. A funnel plot was constructed for all included trials collectively due to the minimal RCTs available in each intervention category. The funnel plot (Figure 2) showed slight asymmetry, revealing possible publication bias. Frequency and imaging intervention results provided a moderate quality of evidence after considering all GRADE factors, whereas biological test and practitioner type interventions provided a low quality of evidence, primarily due to the number of trials and events in each of these intervention categories (Table 4).

\section{Results of Individual Studies}

Extracted event data, effect measures with associated CIs, and p-values are presented in Table 3 for all comparisons described in each RCT. Only 8/23 (35\%) of comparisons reported effect measures, and event rate data could be extracted from all but one RCT (two comparisons) ${ }^{29}$. All RCTs reported p-values, however, four comparisons simply indicated results were not significant but did not provide point estimates ${ }^{25,29,37}$. Computed effect estimates (RR) for are presented in Figure 3 for frequency interventions, Figure 4 for imaging interventions and in Figure 5 for practitioner type interventions. The biological intervention $R R$ is described in the results section below, as a meta-analysis could not be conducted for this category due to insufficient data.

\section{Synthesis of Results}

Seventeen trials (21 comparisons) were included in the meta-analysis as one trial did not present event rate data. The summary of results are presented in Table 4 along with the GRADE quality of evidence.

\section{Biological Test Interventions}

As only one trial was categorized as a biological test intervention, a meta-analysis could not be conducted. This trial which evaluated colorectal cancer patients demonstrated no difference in more intensive versus less intensive biological test surveillance protocols on OS (RR: 0.96, 95\% CI: $0.75-1.23)$.

\section{Frequency Interventions}


A total of six trials were included in the pooled effect size estimates for frequency interventions resulting in a total of 2997 patients analyzed. Heterogeneity was moderate for all combined trials, but this was not statistically significant $\left(\mathrm{I}^{2}=53 \%\right.$, $\mathrm{p}$-value $\left.=0.06\right)$. The combined risk ratio was 0.96 (95\% CI: 0.79-1.16), indicating no significant difference in OS between more intensive and less intensive post-operative frequency protocols (Figure 4). In the subgroup analysis of cancer types, the test for subgroup differences was not statistically significant $(\mathrm{p}=0.12)$.

\section{Imaging Interventions}

A total of 12 trials were included in the pooled effect size estimates for imaging interventions resulting in a total of 7194 patients analyzed. Heterogeneity was low $\left(\mathrm{I}^{2}=0 \%\right)$. The combined risk ratio was 0.99 (95\% CI: 0.91-1.08), indicating no significant difference in OS between more intensive and less intensive post-operative imaging protocols (Figure 5). In the subgroup analysis of cancer types, the test for subgroup differences was not statistically significant $(\mathrm{p}=0.67)$.

\section{Practitioner Type Interventions}

A total of two trials were included in the pooled effect size estimates for practitioner type interventions resulting in a total of 467 patients analyzed. Heterogeneity was low $\left(\mathrm{I}^{2}=0 \%\right)$. The combined risk ratio was 1.10 (95\% CI: 0.64-1.91), indicating no significant difference in OS when using more specialized versus less specialized health care personnel for post-operative surveillance (Figure 6). There was insufficient data to perform subgroup analysis by cancer type.

\section{Discussion}

\section{Summary of Results Quality of the Evidence}

The purpose of this study was to investigate the effect of less intense post-operative biological test surveillance, frequency surveillance, imaging surveillance or practitioner type surveillance on OS in cancer patients that have undergone a solid tumor resection with curative intent. This is the only meta-analysis to our knowledge that evaluates all cancer types in each surveillance category and identifies the category of each surveillance protocol. No difference in OS was observed for all pooled effect estimates in any of frequency interventions, imaging interventions or practitioner type interventions. Furthermore, there was no difference in OS survival for any of the analyses when analyzing cancer type subgroups separately. However, it is worth noting that only colorectal 
cancer for frequency and imaging interventions and breast cancer for imaging interventions had sufficient data to conduct a subgroup analyses due to insufficient number of RCTs for all other cancer types.

\section{Implications and Discussion}

By the end of 2020, the cost of cancer care in the United States is expected to be $\$ 157.8$ billion (USD), becoming one of the most expensive medical conditions ${ }^{43}$. Advancements in oncology treatment have resulted in a growing number of cancer survivors that continue to utilize healthcare resources for longer periods of time ${ }^{44}$. This calls into question the ability of our healthcare systems to meet the needs of patients, as both the number of primary care physicians and medical specialists, and available funds in the healthcare system are limited ${ }^{44}$. It is therefore essential to devote research efforts to develop effective strategies in cancer care to reduce the strain on the healthcare system.

Routine follow-up after tumor resection surgery varies significantly among both country specific guidelines and physicians. Physician surveys and systematic reviews evaluating post-operative surveillance strategies report a lack of consensus in surveillance practice and an inability to provide recommendations on the most appropriate protocol due to high variability and minimal highquality data ${ }^{45-47}$. Among included articles in this systematic review and meta-analysis, no two trials evaluated identical interventions in post-operative surveillance, emphasizing that clinical equipoise may exist with respect to how patients are followed after definitive treatment. Although surveillance recommendations should be cancer type specific, even when post-operative surveillance strategies were evaluated by cancer subgroups, variations were prevalent in the frequency of clinic visits, types of imaging or biological tests employed, and types of healthcare workers involved in the post-operative surveillance program. As these variations can be explained and are expected in surgical RCTs, the evidence was not downgraded due to inconsistency. However, it is important to note that cancer subgroup estimates should be considered by guideline developers, due to variations in treatment and disease prognosis across cancer types. A metaanalysis assumes that the magnitude of effect is similar across the range of patients, interventions, and ways of measuring outcomes ${ }^{48}$. Patients, intervention specifics, and ways of measuring outcomes were not considered in the effect estimate, which could lead to inaccurate conclusions. 
Overall survival measures ranged from a two-year follow-up analysis to a five-year follow-up analysis, possibly attributing to differing survival outcomes. We recommend that the results of this meta-analysis are viewed in light of these dissimilarities. Additional large RCTs with similar surveillance programs would need to be conducted for each cancer type in order to evaluate OS and provide recommendations for clinicians.

Although this meta-analysis evaluated only the effect of more intensive versus less intensive biological test surveillance, frequency surveillance, imaging surveillance or practitioner type surveillance strategies on OS, secondary outcomes including costs to the healthcare system and patient's quality of life should also be considered when recommending an optimal post-operative surveillance protocol. A systematic review of breast cancer surveillance programs reported that the adoption of less intensive surveillance programs that do not compromise overall survival can result in savings upward of $\$ 8,000$ USD per patient per quality adjusted life year ${ }^{49}$. Furthermore, patient anxiety due to harmful levels of radiation from more intensive imaging modalities, and burdens due to more frequent follow-up visits could be reduced by a less intensive surveillance program. It is however important to note that patient psychological factors were not assessed in this meta-analysis, and future RCTs that evaluate post-operative surveillance programs on OS should also consider patient quality of life and a healthcare cost-analysis as important secondary outcomes.

Previous systematic reviews and meta-analyses of colorectal cancer demonstrated that intensive follow-up after curative resection for colorectal cancer improved survival at five years, conflicting with the results presented here ${ }^{46,50-53}$. Limitations of the aforementioned studies include limited quantities of articles and the high risk of bias in the included trials. Furthermore, these metaanalyses, and its' included trials, predate advancements in the management of cancer, including wider tumor resection and the use of combined therapies, which have been documented to improve survival $^{54}$. Consequently, we believe our meta-analysis provides the most up-to-date evidence on post-operative colorectal cancer surveillance programs. It is however essential that all types of cancer continue to investigate post-operative surveillance programs by way of large RCTs, in order to inform high-quality, evidence-based recommendations on post-operative follow-up programs. 


\section{Limitations}

Despite the large sample size of this systematic review and meta-analysis, this study has some limitations. All patients in the RCT were post-operative patients who were treated for a solid tumor, excluding many trials and cancer types that are primarily treated by chemotherapy and radiation. Moreover, although there was generally a low risk of bias across all included trials, when extracting statistical information and further details about peri-operative treatment or baseline data of patients, many of these variables were not reported, highlighting the limited information reported in each trial. This may be due to the publication year of many of the trials, in which reporting guidelines prior to 2001 when more robust CONSORT guidelines were established. Adjuvant and neoadjuvant therapies, as well as tumor stage are also associated with prognosis in patients and may introduce bias as these variables were not considered in this meta-analysis. Furthermore, although the number of included studies was high for all intervention types, when interventions were categorized, minimal data was available for both biological test interventions and practitioner type interventions. Similarly, as very few studies were included in each subgroup analyses, these analyses could be underpowered. However, the confidence intervals for the subgroups overlap substantially so it is unlikely that there is a subgroup difference.

\section{Quality of the Evidence}

As this study evaluated RCTs, and the risk of bias was generally low across studies, the quality of evidence was not downgraded due to limitations in study design. Although every study had a high risk of bias for blinding of study participants and personnel, blinding in this manner was not possible for the type of interventions assessed, and therefore would not contribute to a high risk of bias in these studies. Reported effect measures were very similar in all included studies as demonstrated by the low $\mathrm{I}^{2}$ value in each analysis. Although inconsistency remains across patients, interventions, and outcome measures even when evaluating each cancer subgroup separately, this is expected in surgical RCTs and does not warrant a downgrade in the level of evidence. All included RCTs were relevant to our research question, and provided insight to OS rates when different surveillance interventions were employed. Although there were differences in the population, interventions and outcome measures, the results provide an overview of intensive versus less intensive intervention strategies in post-operative surveillance for cancer patients, which is the overarching focus of this systematic review, and therefore the quality of evidence was 
not downgraded due to indirectness of evidence. Biological test interventions and practitioner type intervention categories only included one and two trials, respectively. Due to the minimal amount of evidence, the low number of events, and the larger confidence intervals for these two categories, the quality of evidence was downgraded for imprecision. Both frequency and imaging interventions included multiple comparisons, meeting the optimal information size criteria and have small confidence intervals, therefore, these results were not downgraded for imprecision. As noted by the funnel plot, there is slight publication bias in the included studies. Therefore, the quality of evidence in each category is downgraded due to publication bias. Overall, frequency and imaging results provide a moderate quality of evidence after consideration of all factors, whereas biological test and practitioner type interventions provide a low quality of evidence, principally due to the lack of trials available to assess these intervention types.

\section{Conclusion}

In this systematic review and meta-analysis, we found that a less intensive post-operative biological test surveillance, frequency surveillance, imaging surveillance or practitioner type surveillance program had no effect on OS following solid tumor resection surgery. However, clinical equipoise persists, and the optimal surveillance protocol for each cancer type should continue to be investigated in large RCTs powered to evaluate OS, while also considering patientimportant outcomes and health system costs.

\section{Funding}

McMaster University is the sponsor of this review. No funding has been received for this study. 

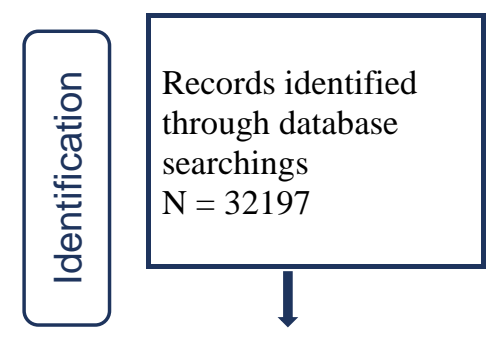

Additional records

identified through other

sources

$\mathrm{N}=19$

Records after duplicates removed $\mathrm{N}=25825$

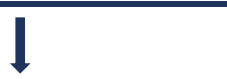

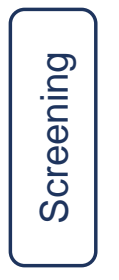

Records screened

$\mathrm{N}=25825$

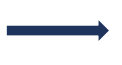

Records excluded $\mathrm{N}=25772$

Title Screening $(\mathrm{N}=25326)$

Abstract Screening $(\mathrm{N}=446)$

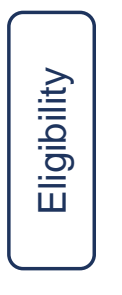

Full-text articles assessed for eligibility $\mathrm{N}=53$

Full-text articles excluded, with reasons $\mathrm{N}=32$

Participants had metastases at time of inclusion in RCT: 1

Cancer not treated with surgery prior to inclusion in RCT: 3

Post-operative follow-up regimens not assessed: 2

Overall survival was not a primary or secondary outcome: 14

Conference Abstract: 7

Preliminary results (no OS reported):4

Dissertation: 1

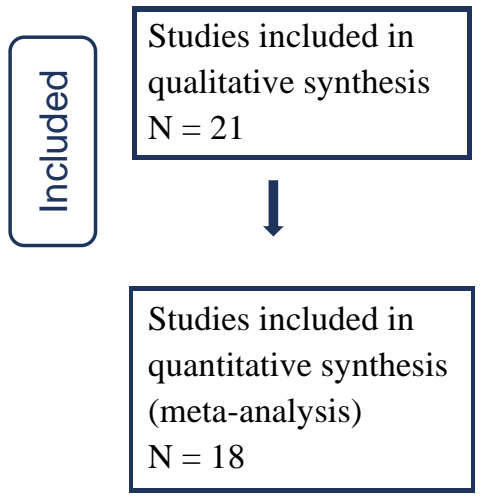

Figure 1: PRISMA flow diagram 
Table 1: Study characteristics of included studies.

\begin{tabular}{|c|c|c|c|c|c|c|c|c|}
\hline & $\begin{array}{c}\text { Country of } \\
\text { Initiating Centre }\end{array}$ & $\begin{array}{l}\text { Cancer } \\
\text { Type }\end{array}$ & $\begin{array}{l}\text { Type of } \\
\text { Trial }\end{array}$ & Groups & Intervention Strategies & $\begin{array}{l}\text { Sample } \\
\text { Size }\end{array}$ & $\begin{array}{l}\text { Follow- } \\
\text { up Time } \\
\text { Frame }\end{array}$ & $\begin{array}{l}\text { Single Centre } \\
\text { or Multi- } \\
\text { Centre }\end{array}$ \\
\hline \multirow[t]{2}{*}{$\begin{array}{l}\text { Ghezzi et al., } \\
\quad 1994^{21}\end{array}$} & \multirow[t]{2}{*}{ Italy } & \multirow[t]{2}{*}{$\begin{array}{l}\text { Breast } \\
\text { cancer }\end{array}$} & \multirow[t]{2}{*}{$\begin{array}{l}\text { Parallel } \\
\text { Group }\end{array}$} & Intensive & $\begin{array}{l}\text { Clinic visits every } 3 \text { months the first } 2 \text { years, then every } 6 \text { months the } \\
\text { following } 3 \text { years; blood test at every visit; mammography annually; } \\
\text { chest X-ray every } 6 \text { months; bone scan and liver echography annually }\end{array}$ & \multirow[t]{2}{*}{1320} & \multirow[t]{2}{*}{5 Years } & \multirow[t]{2}{*}{ Multi-Centre } \\
\hline & & & & Control & $\begin{array}{l}\text { Clinic visits every } 3 \text { months the first } 2 \text { years, then every } 6 \text { months the } \\
\text { following } 3 \text { years; mammography annually. }\end{array}$ & & & \\
\hline $\begin{array}{l}\text { Kjeldsen et } \\
\text { al., } 1997^{22}\end{array}$ & Denmark & $\begin{array}{l}\text { Colorectal } \\
\text { cancer }\end{array}$ & $\begin{array}{l}\text { Parallel } \\
\text { Group }\end{array}$ & Intensive & $\begin{array}{l}\text { Clinic visits every } 6 \text { months the first } 3 \text { years, then at } 48,60,120,150 \\
\text { and } 180 \text { months post-operatively }\end{array}$ & 597 & 5 years & Single-centre \\
\hline \multirow[t]{2}{*}{$\begin{array}{l}\text { Koinberg et } \\
\text { al., } 2004^{23}\end{array}$} & \multirow[t]{2}{*}{ Sweden } & \multirow[t]{2}{*}{$\begin{array}{l}\text { Breast } \\
\text { cancer }\end{array}$} & \multirow[t]{2}{*}{$\begin{array}{l}\text { Parallel } \\
\text { Group }\end{array}$} & Intensive & $\begin{array}{l}\text { Specialist Physician visits every } 3 \text { months the first } 2 \text { years, then every } 6 \\
\text { months the following } 2 \text { years and thereafter annually; annual } \\
\text { mammography }\end{array}$ & \multirow[t]{2}{*}{264} & \multirow[t]{2}{*}{5 Years } & \multirow[t]{2}{*}{ Multi-Centre } \\
\hline & & & & Control & $\begin{array}{l}\text { Specialist nurse check-up visits if requested by patient; annual } \\
\text { mammography }\end{array}$ & & & \\
\hline \multirow[t]{3}{*}{$\begin{array}{l}\text { Kokko et al., } \\
2005^{24,25}\end{array}$} & \multirow[t]{3}{*}{ Finland } & \multirow[t]{3}{*}{$\begin{array}{l}\text { Breast } \\
\text { cancer }\end{array}$} & \multirow[t]{3}{*}{ Factorial } & Intensive & $\begin{array}{l}\text { Routine Diagnostic tests of blood tests, liver enzymes; Ca } 15-3 \\
\text { markers, and CXRs every } 6 \text { months; mammogram annually; Liver US } \\
\text { and bone scan every } 2 \text { years }\end{array}$ & \multirow[t]{3}{*}{472} & \multirow[t]{3}{*}{5 years } & \multirow[t]{3}{*}{ Single-centre } \\
\hline & & & & Control & Clinically Indicated Diagnostic tests & & & \\
\hline & & & & Control & Clinic visits every 6 months & & & \\
\hline \multirow[t]{2}{*}{$\begin{array}{l}\text { Makela et al., } \\
\quad 1995^{26,27}\end{array}$} & \multirow[t]{2}{*}{ Finland } & \multirow[t]{2}{*}{$\begin{array}{l}\text { Colorectal } \\
\text { cancer }\end{array}$} & \multirow[t]{2}{*}{$\begin{array}{l}\text { Parallel } \\
\text { Group }\end{array}$} & Intensive & $\begin{array}{l}\text { Clinic visit every } 3 \text { months the first } 2 \text { years, then every } 6 \text { months the } \\
\text { next } 3 \text { years; CBC, CEA, tests of occult fecal bleeding and chest x-ray } \\
\text { at every visit; video colonoscopy (or fibresigmoidoscopy) annually; } \\
\text { liver US every } 6 \text { months; CT of the liver and primary resection site } \\
\text { annually. }\end{array}$ & \multirow[t]{2}{*}{106} & \multirow[t]{2}{*}{5 years } & \multirow[t]{2}{*}{ Single-centre } \\
\hline & & & & Control & $\begin{array}{l}\text { Clinic visit every } 3 \text { months the first } 2 \text { years, then every } 6 \text { months the } \\
\text { next } 3 \text { years; CBC, CEA, tests of occult fecal bleeding and chest } x \text {-ray } \\
\text { at every visit; rigid sigmoidoscopy at every visit for patients with rectal } \\
\text { or sigmoid cancers; barium enema for all patients annually. }\end{array}$ & & & \\
\hline \multirow{2}{*}{$\begin{array}{l}\text { Monteil et } \\
\text { al., } 2010^{28}\end{array}$} & \multirow[t]{2}{*}{ France } & Lung & Parallel & Intensive & CDET and Brain CT every 6 months for 2 years & 69 & 2 years & Single-centre \\
\hline & & Cancer & лосир & Control & $\begin{array}{l}\text { Chest, liver and adrenal gland CT, abdominal US, bone scintigraphy if } \\
\text { there were bone symptoms every } 6 \text { months for } 2 \text { years }\end{array}$ & & & \\
\hline
\end{tabular}




\begin{tabular}{|c|c|c|c|c|c|c|c|c|}
\hline $\begin{array}{l}\text { Ohlsson et } \\
\text { al., } 1995^{29}\end{array}$ & Sweden & $\begin{array}{l}\text { Colorectal } \\
\text { cancer }\end{array}$ & $\begin{array}{l}\text { Parallel } \\
\text { Group }\end{array}$ & Intensive & $\begin{array}{l}\text { Clinic visits every } 3 \text { months the first } 2 \text { years, then every } 6 \text { months the } \\
\text { next } 2 \text { years, thereafter annually; CEA, proctosigmoidscopy, fecal } \\
\text { hemoglobin, and CXR at every visit; endoscopic control of } \\
\text { anastomosis at } 9,21 \text { and } 42 \text { months; complete colonoscopy at } 3,15,30 \\
\text { and } 60 \text { months; CT of pelvis (for required patients) at } 3,6,12,18 \text {, and } \\
24 \text { months. }\end{array}$ & 107 & 5 years & Multi-Centre \\
\hline \multirow[t]{2}{*}{$\begin{array}{l}\text { Pietra et al., } \\
\quad 1998^{30}\end{array}$} & \multirow[t]{2}{*}{ Italy } & \multirow[t]{2}{*}{$\begin{array}{l}\text { Colorectal } \\
\text { cancer }\end{array}$} & \multirow[t]{2}{*}{$\begin{array}{l}\text { Parallel } \\
\text { Group }\end{array}$} & Intensive & $\begin{array}{l}\text { Clinic visits every } 3 \text { months the first } 2 \text { years, then every } 6 \text { months the } \\
\text { next } 3 \text { years and annually thereafter; US and CEA test at every visit; } \\
\text { CXR and colonoscopy annually. }\end{array}$ & \multirow[t]{2}{*}{207} & \multirow[t]{2}{*}{5 years } & \multirow[t]{2}{*}{ Single-centre } \\
\hline & & & & Control & $\begin{array}{l}\text { Clinic visits every } 6 \text { the first year, thereafter annually after; US and } \\
\text { CEA test at every visit; CXR, Colonoscopy and CT annually. }\end{array}$ & & & \\
\hline \multirow[t]{3}{*}{$\begin{array}{l}\text { Primrose et } \\
\text { al., } 2014^{31}\end{array}$} & \multirow[t]{3}{*}{ United Kingdom } & \multirow[t]{3}{*}{$\begin{array}{l}\text { Colorectal } \\
\text { cancer }\end{array}$} & \multirow[t]{3}{*}{ Factorial } & Intensive & $\begin{array}{l}\text { CEA test every } 3 \text { months for } 2 \text { years, then every } 6 \text { months for } 3 \text { years; } \\
\text { Chest, abdomen and pelvis CT scan every } 6 \text { months for } 2 \text { years, then } \\
\text { annually for } 3 \text { years. } \\
\text { CEA test every } 3 \text { months for } 2 \text { years, then every } 6 \text { months for } 3 \text { years; } \\
\text { Chest, abdomen and pelvis CT scan at } 12-18 \text { months if requested at } \\
\text { study entry by clinician. }\end{array}$ & \multirow[t]{3}{*}{1202} & \multirow[t]{3}{*}{5 years } & \multirow[t]{3}{*}{ Multi-Centre } \\
\hline & & & & & $\begin{array}{l}\text { Chest, abdomen and pelvis CT scan every } 6 \text { months for } 2 \text { years, then } \\
\text { annually for } 3 \text { years. }\end{array}$ & & & \\
\hline & & & & Control & $\begin{array}{l}\text { No scheduled follow-up; Chest, abdomen and pelvis CT scan at 12-18 } \\
\text { months if requested at study entry by clinician. }\end{array}$ & & & \\
\hline \multirow{4}{*}{$\begin{array}{l}\text { Puri et al., } \\
2018^{32,33}\end{array}$} & \multirow[t]{4}{*}{ India } & \multirow{4}{*}{$\begin{array}{l}\text { Bone and } \\
\text { soft tissue } \\
\text { sarcoma }\end{array}$} & \multirow[t]{4}{*}{ Factorial } & Intensive & Clinic visits every 3 months & \multirow[t]{4}{*}{495} & \multirow[t]{4}{*}{5 years } & \multirow[t]{4}{*}{ Single-centre } \\
\hline & & & & Control & Clinic visits every 6 months & & & \\
\hline & & & & Intensive & Chest CTs & & & \\
\hline & & & & Control & CXRs & & & \\
\hline \multirow[t]{2}{*}{$\begin{array}{l}\text { Rodriguez- } \\
\text { Moranta et } \\
\text { al., } 2006^{34}\end{array}$} & \multirow[t]{2}{*}{ Spain } & \multirow[t]{2}{*}{$\begin{array}{l}\text { Colorectal } \\
\text { cancer }\end{array}$} & \multirow[t]{2}{*}{$\begin{array}{l}\text { Parallel } \\
\text { Group }\end{array}$} & Intensive & $\begin{array}{l}\text { Clinic visits every } 3 \text { months the first } 2 \text { years and every } 6 \text { months the } \\
\text { following } 3 \text { years; CBC, CEA and liver function tests at every visit; } \\
\text { abdominal CT every } 6 \text { months the first } 2 \text { years then annually the } \\
\text { following } 3 \text { years; CXR and colonoscopy annually }\end{array}$ & \multirow[t]{2}{*}{259} & \multirow[t]{2}{*}{5 years } & \multirow[t]{2}{*}{ Multi-Centre } \\
\hline & & & & Control & $\begin{array}{l}\text { Clinic visits every } 3 \text { months the first } 2 \text { years and every } 6 \text { months the } \\
\text { following } 3 \text { years; CBC, CEA and liver function tests at every visit; } \\
\text { colonoscopy at year } 1 \text { and year } 3\end{array}$ & & & \\
\hline
\end{tabular}




\begin{tabular}{|c|c|c|c|c|c|c|c|c|}
\hline \multirow[t]{2}{*}{$\begin{array}{l}\text { Rosati et al., } \\
2015^{35}\end{array}$} & \multirow[t]{2}{*}{ Italy } & \multirow[t]{2}{*}{$\begin{array}{l}\text { Colorectal } \\
\text { cancer }\end{array}$} & \multirow[t]{2}{*}{$\begin{array}{l}\text { Parallel } \\
\text { Group }\end{array}$} & Intensive & $\begin{array}{l}\text { Colon: Clinic visits every } 4 \text { months the first } 2 \text { years, then every } 6 \\
\text { months the next } 2 \text { years, then annually the } 5 \text { th year; CEA and CBC } \\
\text { tests at every visit; colonoscopy and chest X-ray annually; Liver } \\
\text { ultrasound every } 4 \text { months the first year, then annually } \\
\text { Rectum: Clinic visits and rectal exam every } 4 \text { months the first } 2 \text { years, } \\
\text { then every } 6 \text { months the next } 2 \text { years, then annually the } 5 \text { th year; CEA } \\
\text { and CBC tests at every visit; colonoscopy and chest x-ray annually; } \\
\text { Liver ultrasound every } 4 \text { months the first year, then annually; } \\
\text { proctoscopy at } 4 \text { and } 8 \text { months; abdomen pelvic CT at } 4,12,24 \text { and } 48 \\
\text { months }\end{array}$ & \multirow[t]{2}{*}{1228} & \multirow[t]{2}{*}{5 years } & \multirow[t]{2}{*}{ Multi-Centre } \\
\hline & & & & Control & $\begin{array}{l}\text { Colon: Clinic visits every } 4 \text { months the first } 2 \text { years, then every } 6 \\
\text { months the next } 2 \text { years, then annually the } 5 \text { th year; CEA tests at every } \\
\text { visit; colonoscopy at } 1 \text { year and } 4 \text { years; Liver ultrasound at } 4 \text { months } \\
\text { and } 16 \text { months. } \\
\text { Rectum: Clinic visits and rectal exam every } 4 \text { months the first } 2 \text { years, } \\
\text { then every } 6 \text { months the next } 2 \text { years, then annually the } 5 \text { th year; CEA } \\
\text { test at every visit; colonoscopy at } 12 \text { and } 48 \text { months; Chest x-ray at } 12 \\
\text { months; Liver US at } 8 \text { and } 16 \text { months }\end{array}$ & & & \\
\hline \multirow[t]{2}{*}{$\begin{array}{l}\text { Rosselli Del } \\
\text { Turco et al., } \\
\quad 1994^{36}\end{array}$} & \multirow[t]{2}{*}{ Italy } & \multirow[t]{2}{*}{$\begin{array}{l}\text { Breast } \\
\text { cancer }\end{array}$} & \multirow[t]{2}{*}{$\begin{array}{l}\text { Parallel } \\
\text { Group }\end{array}$} & Intensive & $\begin{array}{l}\text { Clinic visits every } 3 \text { months the first } 2 \text { years, then every } 6 \text { months the } \\
\text { following } 3 \text { years. Mammography annually; CXR and bone scan every } \\
6 \text { months. }\end{array}$ & \multirow[t]{2}{*}{1243} & \multirow[t]{2}{*}{5 years } & \multirow[t]{2}{*}{ Multi-Centre } \\
\hline & & & & Control & $\begin{array}{l}\text { Clinic visits every } 3 \text { months the first } 2 \text { years, then every } 6 \text { months the } \\
\text { following } 3 \text { years; mammography annually. }\end{array}$ & & & \\
\hline \multirow[t]{2}{*}{$\begin{array}{l}\text { Schoemaker } \\
\text { et al., } 1998^{37}\end{array}$} & \multirow[t]{2}{*}{ Australia } & \multirow[t]{2}{*}{$\begin{array}{l}\text { Colorectal } \\
\text { cancer }\end{array}$} & \multirow[t]{2}{*}{$\begin{array}{l}\text { Parallel } \\
\text { Group }\end{array}$} & Intensive & $\begin{array}{l}\text { Clinic visits every } 3 \text { months for } 2 \text { years, then every } 6 \text { months for } 5 \\
\text { years; CBC, LFTs, CEA and fecal occult blood tests at every visit; } \\
\text { CXR, CT of the liver and colonoscopy annually }\end{array}$ & \multirow[t]{2}{*}{325} & \multirow[t]{2}{*}{5 years } & \\
\hline & & & & Control & $\begin{array}{l}\text { Clinic visits every } 3 \text { months for } 2 \text { years, then every } 6 \text { months for } 5 \\
\text { years; CBC, LFTs, CEA and fecal occult blood tests at every visit }\end{array}$ & & & \\
\hline \multirow[t]{2}{*}{$\begin{array}{l}\text { Secco et al., } \\
2002^{38}\end{array}$} & \multirow[t]{2}{*}{ Italy } & \multirow[t]{2}{*}{$\begin{array}{l}\text { Colorectal } \\
\text { cancer }\end{array}$} & \multirow[t]{2}{*}{$\begin{array}{l}\text { Parallel } \\
\text { Group }\end{array}$} & Intensive & $\begin{array}{l}\text { High Risk patients: Clinic visits every } 3 \text { months for the first } 2 \text { years, } \\
\text { then every } 4 \text { months the third year, thereafter every } 6 \text { months; CEA test } \\
\text { at every visit; Abdominal and pelvis US every } 6 \text { months the first } 3 \\
\text { years, then annually; Rigid rectosigmoidoscopy for rectal cancer } \\
\text { patients and CXRs annually. } \\
\text { Low Risk patients: Clinic visits every } 6 \text { months the first } 2 \text { years, } \\
\text { thereafter yearly; CEA test and abdominal pelvic US at every visit; } \\
\text { CXRs annually; Rigid rectosigmoidoscopy for rectal cancer patients } \\
\text { annually for } 2 \text { years, then every } 2 \text { years. }\end{array}$ & \multirow[t]{2}{*}{358} & \multirow[t]{2}{*}{5 years } & \\
\hline & & & & Control & $\begin{array}{l}\text { Minimal follow-up programme performed by physicians for each risk } \\
\text { group }\end{array}$ & & & \\
\hline
\end{tabular}




\begin{tabular}{|c|c|c|c|c|c|c|c|c|}
\hline \multirow[t]{2}{*}{$\begin{array}{l}\text { Sobhani et } \\
\text { al., } 2018^{39}\end{array}$} & \multirow[t]{2}{*}{ France } & \multirow[t]{2}{*}{$\begin{array}{l}\text { Colorectal } \\
\text { cancer }\end{array}$} & \multirow[t]{2}{*}{$\begin{array}{l}\text { Parallel } \\
\text { Group }\end{array}$} & Intensive & $\begin{array}{l}\text { Clinic visits every } 3 \text { months; blood tests, liver function tests and tumor } \\
\text { marker tests at every visit; wbCT and 18FDG-PET/CT every } 6 \text { months; } \\
\text { Liver US and CXR at all visits where wbCT did not occur; } \\
\text { colonoscopy at year } 1 \text { and } 3 \text {. }\end{array}$ & \multirow[t]{2}{*}{239} & \multirow[t]{2}{*}{3 years } & \multirow[t]{2}{*}{ Multi-Centre } \\
\hline & & & & Control & $\begin{array}{l}\text { Clinic visits every } 3 \text { months; blood tests, liver function tests and tumor } \\
\text { marker tests at every visit; wbCT every } 6 \text { months; Liver US and CXR } \\
\text { at all visits where wbCT did not occur; colonoscopy at year } 1 \text { and } 3 \text {. }\end{array}$ & & & \\
\hline $\begin{array}{l}\text { Wang et al., } \\
\qquad 2009^{40}\end{array}$ & China & $\begin{array}{l}\text { Colorectal } \\
\text { cancer }\end{array}$ & $\begin{array}{l}\text { Parallel } \\
\text { Group }\end{array}$ & Intensive & $\begin{array}{l}\text { Clinic visits every } 3 \text { months the first year, then every } 6 \text { months the next } \\
2 \text { years, then annually; CEA test, CXR, liver imaging and colonoscopy } \\
\text { performed at every visit. }\end{array}$ & 326 & 5 years & Single-centre \\
\hline $\begin{array}{l}\text { Wattchow et } \\
\text { al., } 2006^{41}\end{array}$ & Australia & $\begin{array}{l}\text { Colon } \\
\text { cancer }\end{array}$ & $\begin{array}{l}\text { Parallel } \\
\text { Group }\end{array}$ & Intensive & $\begin{array}{l}\text { Followed by Surgeon; Visits every } 3 \text { months for the first } 2 \text { years, then } \\
\text { every } 6 \text { months for the next } 3 \text { years; faecal occult blood tests every } \\
\text { year; colonoscopy every } 3 \text { years }\end{array}$ & 203 & 2 years & Multi-Centre \\
\hline
\end{tabular}

CEA $=$ Carcinoembryonic antigen, $\mathrm{CT}=$ Computed tomography, $\mathrm{CXR}=$ Chest Radiograph $(\mathrm{X}$-Ray $), \mathrm{CBC}=$ complete blood count, $\mathrm{CDET}=$ coincidence detection emission tomography, FDG - flurodeoxyglucose, LFT = liver function tests , US = ultrasonography, wbCT = whole body computed tomography, GP = general practitioner, PET $=$ positron emission tomography 


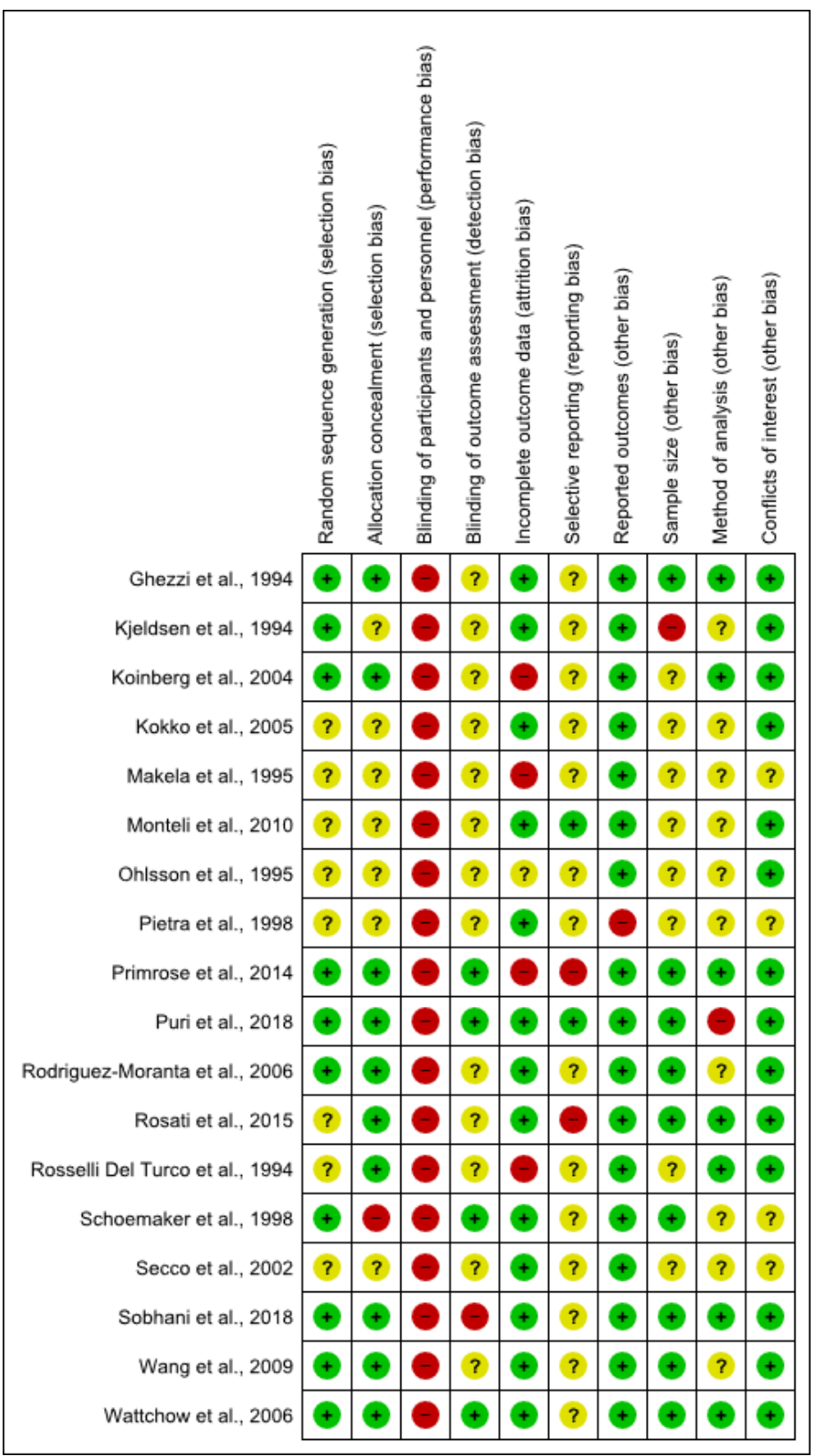

Table 2: Risk and quality assessment of included studies. 


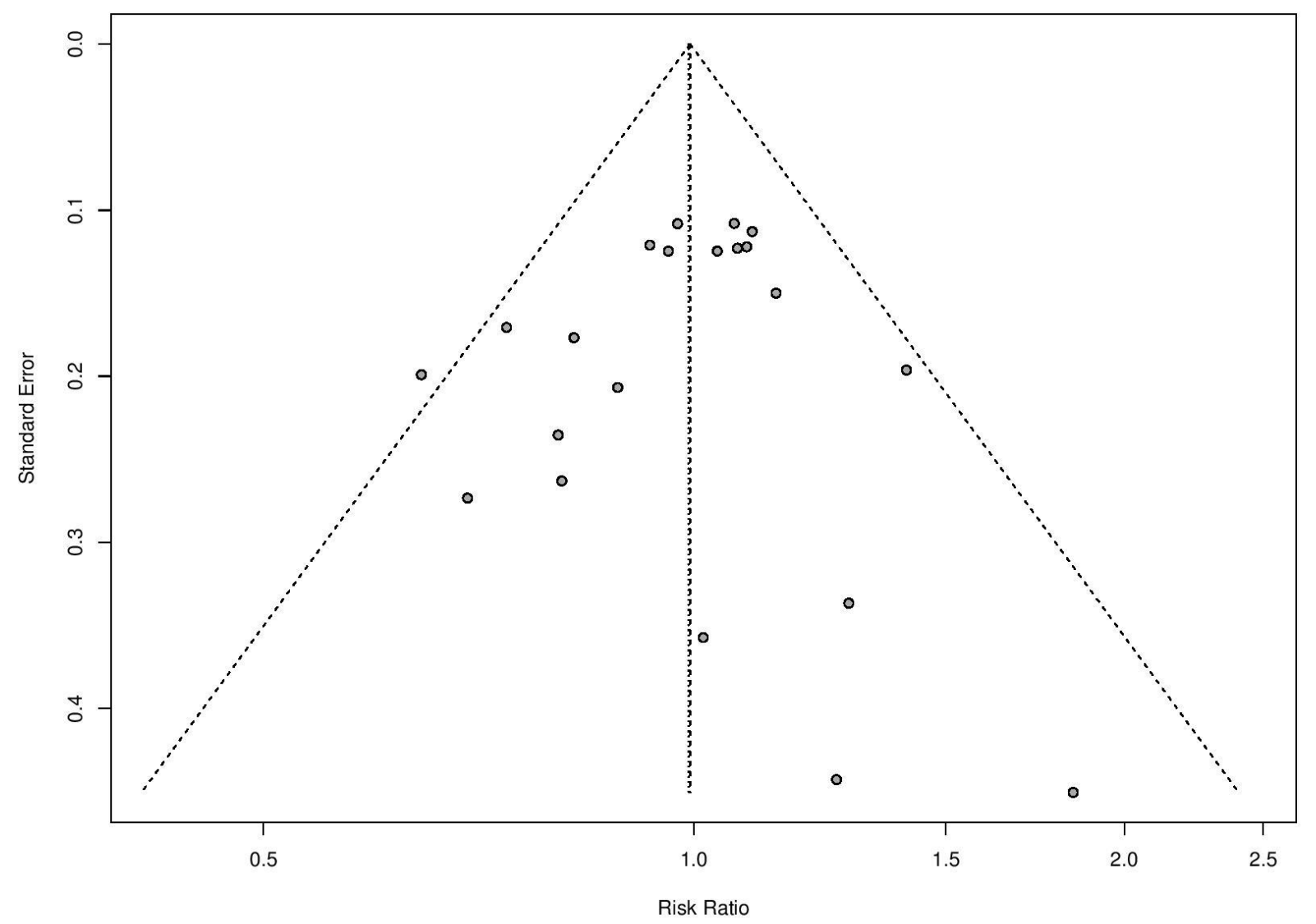

Figure 2: Funnel plot of all included studies. 
Table 3: Reported statistical results for all include comparisons.

\section{Investigated Intervention Strategies}

No. of Patients

No. of Deaths (\%)

Reported

Effect

Measure

\begin{tabular}{|l|l|l|l|} 
Intensive Control Intensive & Control
\end{tabular}

\section{Biological Test Interventions}

No CEA tests

CEA tests

2014

\begin{tabular}{|c|}
\hline $\begin{array}{c}\text { Kjeldsen et al., } \\
1997\end{array}$ \\
\hline $\begin{array}{c}\text { Kokko et al., } \\
2005\end{array}$ \\
\hline $\begin{array}{c}\text { Ohlsson et al., } \\
1995\end{array}$ \\
\hline
\end{tabular}

Pietra et al., 1998

\section{Clinic visits every 3 months} (for required patients) at 3, 6, 12, 18, and 24 months.

Primrose et al. 2014

Puri et al., 2018

Secco et al., 2002
Clinic visits every 6 months the first 3 years, then clinic visits at 48, 60, 120, 150 and 180 months postoperatively

Clinic visits every 3 months the first 2 years, then every 6 months the next 2 years, thereafter annually;

CEA, proctosigmoidscopy, fecal hemoglobin, and

Chest CXR at every visit; endoscopic control of

anastomosis at 9,21 and 42 months; complete

colonoscopy at 3,15, 30 and 60 months; CT of pelvis

Clinic visits every 3 months the first 2 years, then every 6 months the next 3 years and annually thereafter; US and CEA test at every visit; CT, CXR and colonoscopy annually.

\section{Frequency Interventions}

Clinic visits at 60, 120 and 180 months post-operatively

More intensive follow-up including CEA tests, CT scans and clinic visits. Combination of patients from all other 3 factors in the trial

\section{Clinic visits every 6 months}

No active follow-up

hs

239

239

53

54

$0.264^{\mathrm{a}}$

Visits every 6 months the first year, thereafter annually; US and CEA test at every visit; CXR, and Colonoscopy annually.

No scheduled follow-up; Chest, abdomen and pelvis CT scan at 12-18 months if requested at study entry by clinician.

Clinic Visits Every 6 Months

Minimal follow-up of high risk patients
High Risk patients: Clinic visits every 3 months for the first 2 years, then every 4 months the third year, thereafter every 6 months; CEA test at every visit;

Abdominal and pelvis US every 6 months the first 3 ypothesis

Test P-

Value 


\begin{tabular}{|c|c|c|c|c|c|c|c|c|}
\hline & $\begin{array}{l}\text { years, then annually; Rigid rectosigmoidoscopy for } \\
\text { rectal cancer patients and Chest CXRs annually. }\end{array}$ & & & & & & & \\
\hline $\begin{array}{l}\text { Secco et al., } \\
\quad 2002\end{array}$ & $\begin{array}{l}\text { Low Risk patients: Clinic visits every } 6 \text { months the } \\
\text { first } 2 \text { years, thereafter yearly; CEA test and } \\
\text { abdominal pelvic US at every visit; Chest CXRs } \\
\text { annually; Rigid rectosigmoidoscopy for rectal cancer } \\
\text { patients annually for } 2 \text { years, then every } 2 \text { years. }\end{array}$ & $\begin{array}{l}\text { Minimal follow-up of low risk } \\
\text { patients }\end{array}$ & 84 & 61 & NR & NR & NR & $<0.01^{\mathrm{a} * *}$ \\
\hline \multicolumn{9}{|c|}{ Imaging Interventions } \\
\hline $\begin{array}{l}\text { Ghezzi et al., } \\
\quad 1994\end{array}$ & $\begin{array}{c}\text { Clinic visits every } 3 \text { months the first } 2 \text { years, then } \\
\text { every } 6 \text { months the following } 3 \text { years; blood test at } \\
\text { every visit; mammography annually; chest } \mathrm{X} \text {-ray } \\
\text { every } 6 \text { months; bone scan and liver echography } \\
\text { annually }\end{array}$ & $\begin{array}{l}\text { Clinic visits every } 3 \text { months the first } \\
2 \text { years, then every } 6 \text { months the } \\
\text { following } 3 \text { years; mammography } \\
\text { annually. }\end{array}$ & 655 & 665 & $132(20)$ & $\begin{array}{l}122 \\
(18)\end{array}$ & $\begin{array}{l}\text { OR: } 1.12 \\
\text { (95\% CI: } \\
0.87- \\
1.43)\end{array}$ & $0.42^{\mathrm{a}}$ \\
\hline $\begin{array}{l}\text { Kokko et al., } \\
\quad 2005\end{array}$ & $\begin{array}{l}\text { Routine diagnostic tests which included: blood test, } \\
\text { liver enzymes and Ca } 15-3 \text { marker tests; CXRs every } \\
6 \text { months, Liver US and bone scan every } 2 \text { years; }\end{array}$ & $\begin{array}{l}\text { All diagnostic tests only when } \\
\text { clinically indicated }\end{array}$ & 243 & 229 & $29(12)$ & $34(15)$ & NR & NS \\
\hline $\begin{array}{l}\text { Makela et al., } \\
\quad 1995\end{array}$ & $\begin{array}{l}\text { Clinic visit every } 3 \text { months the first } 2 \text { years, then } \\
\text { every } 6 \text { months the next } 3 \text { years; CBC, CEA, tests of } \\
\text { occult fecal bleeding and chest X-ray at every visit; } \\
\text { video colonoscopy (or fibresigmoidoscopy) annually; } \\
\text { liver US every } 6 \text { months; CT of the liver and primary } \\
\text { resection site annually. }\end{array}$ & $\begin{array}{l}\text { Clinic visit every } 3 \text { months the first } 2 \\
\text { years, then every } 6 \text { months the next } 3 \\
\text { years; CBC, CEA, tests of occult } \\
\text { fecal bleeding and chest x-ray at } \\
\text { every visit; rigid sigmoidoscopy at } \\
\text { every visit for patients with rectal or } \\
\text { sigmoid cancers; barium enema for } \\
\text { all patients annually. }\end{array}$ & 52 & 54 & $23(44)$ & $27(50)$ & NR & $0.5^{\mathrm{a}}$ \\
\hline $\begin{array}{l}\text { Monteil et al., } \\
\quad 2010\end{array}$ & CDET and Brain CT every 6 months for 2 years & $\begin{array}{l}\text { Chest, liver and adrenal gland CT, } \\
\text { abdominal US, bone scintigraphy if } \\
\text { there were bone symptoms every } 6 \\
\text { months for } 2 \text { years }\end{array}$ & 36 & 33 & $14(39)$ & $10(30)$ & NR & $\mathrm{NS}^{\mathrm{b}}$ \\
\hline $\begin{array}{l}\text { Primrose et al., } \\
\quad 2014\end{array}$ & Chest CT scans & No Chest CT scans & 601 & 601 & $108(18)$ & $\begin{array}{l}104 \\
(17)\end{array}$ & NR & $0.76^{\mathrm{a}}$ \\
\hline Puri et al., 2018 & CT Scans & CXRs & 196 & 216 & $92(47)$ & $95(44)$ & $\begin{array}{l}\text { HR: } 0.94 \\
\text { (90\% CI: } \\
0.78-1.1)\end{array}$ & $0.63^{\mathrm{a}}$ \\
\hline $\begin{array}{l}\text { Rodriguez- } \\
\text { Moranta et al., } \\
\quad 2006\end{array}$ & $\begin{array}{l}\text { Clinic visits every } 3 \text { months the first } 2 \text { years and } \\
\text { every } 6 \text { months the following } 3 \text { years; CBC, CEA } \\
\text { and liver function tests at every visit; abdominal CT } \\
\text { every } 6 \text { months the first } 2 \text { years then annually the }\end{array}$ & $\begin{array}{l}\text { Clinic visits every } 3 \text { months the first } \\
2 \text { years and every } 6 \text { months the } \\
\text { following } 3 \text { years; CBC, CEA and } \\
\text { liver function tests at every visit; } \\
\text { colonoscopy at year } 1 \text { and year } 3\end{array}$ & 127 & 132 & $21(17)$ & $27(26)$ & $\begin{array}{l}\text { HR: } 0.87 \\
\text { (95\% CI: } \\
0.49- \\
1.54)\end{array}$ & $0.62^{\mathrm{d}}$ \\
\hline
\end{tabular}


Rosati et al., 2015

Rosselli Del Turco et al., 1994

Schoemaker et al., 1998

Sobhani et al. 2018

Wang et al., 2009 following 3 years; chest CXR and colonoscopy annually

Colon: Clinic visits every 4 months the first 2 years, then every 6 months the next 2 years, then annually the 5th year; CEA and CBC tests at every visit; colonoscopy and chest $\mathrm{x}$-ray annually; Liver ultrasound every 4 months the first year, then annually

Rectum: Clinic visits and rectal exam every 4 months the first 2 years, then every 6 months the next 2 years, then annually the 5th year; CEA and CBC tests at every visit; colonoscopy and chest $\mathrm{X}$-ray annually; Liver ultrasound every 4 months the first year, then annually; proctoscopy at 4 and 8 months; abdomen pelvic CT at 4, 12, 24 and 48 months

Clinic visits every 3 months the first 2 years, then every 6 months the following 3 years.

Mammography annually; Chest CXR and bone scan every 6 months.

Clinic visits every 3 months for 2 years, then every 6 months for 5 years; CBC, LFTs, CEA and fecal occult blood tests at every visit; CXR, CT of the liver and colonoscopy annually

Clinic visits every 3 months; blood tests, liver function tests and tumor marker tests at every visit; wbCT and 18FDG-PET/CT every 6 months; Liver US and Chest CXR at all visits where wbCT did not occur; colonoscopy at year 1 and 3 .

Clinic visits every 3 months the first year, then every 6 months the next 2 years, then annually; CEA test,

Chest CXR, liver imaging and colonoscopy performed at every visit.
Colon: Clinic visits every 4 months the first 2 years, then every 6 months the next 2 years, then annually the 5 th year; CEA tests at every visit; colonoscopy at 1 year and 4 years; Liver ultrasound at 4 months and 16 months.

Rectum: Clinic visits and rectal exam every 4 months the first 2 years, then every 6 months the next 2 years, then annually the 5 th year; CEA test at every visit; colonoscopy at 12 and 48 months; Chest $\mathrm{x}$-ray at 12 months;

Liver US at 8 and 16 months

Clinic visits every 3 months the first 2 years, then every 6 months the following 3 years; mammography annually.

Clinic visits every 3 months for 2 years, then every 6 months for 5 years; CBC, LFTs, CEA and fecal

occult blood tests at every visit

Clinic visits every 3 months; blood tests, liver function tests and tumor marker tests at every visit; wbCT every 6 months; Liver US and Chest CXR at all visits where wbCT did not occur; colonoscopy at year 1 and 3 .

Clinic visits every 3 months the first year, then every 6 months the next 2 years, then annually; CEA test, Chest $\mathrm{CXR}$, and liver imaging performed at every visit; colonoscopy performed at 6, 30 and 60 months.
HR: 1.14

$0.87-$

1.48)

\begin{tabular}{|c|c|c|c|c|c|}
\hline 622 & 621 & 116 (19) & $\begin{array}{l}121 \\
(19)\end{array}$ & NR & $\mathrm{NS}^{\mathrm{b}}$ \\
\hline 167 & 158 & $43(26)$ & $55(35)$ & $\begin{array}{c}\text { OR: } 0.69 \\
\text { (95\% CI: } \\
0.47- \\
1.04)\end{array}$ & $0.07^{\mathrm{d}}$ \\
\hline 120 & 119 & $13(11)$ & $7(6)$ & $\begin{array}{c}\text { RR: } 1.83 \\
\text { (95\% CI: } \\
0.76- \\
4.42)\end{array}$ & $0.17^{\mathrm{d}}$ \\
\hline 161 & 158 & $42(26)$ & $50(32)$ & $\begin{array}{l}\text { HR: } 1.41 \\
\text { (95\% CI: } \\
0.92- \\
2.14)\end{array}$ & $0.25^{\mathrm{a}}$ \\
\hline
\end{tabular}

\section{Practitioner Type Interventions}




\begin{tabular}{|c|c|c|c|c|c|c|c|c|}
\hline $\begin{array}{l}\text { Koinberg et al., } \\
2004\end{array}$ & $\begin{array}{l}\text { Specialist Physician visits every } 3 \text { months the first } 2 \\
\text { years, then every } 6 \text { months the following } 2 \text { years and } \\
\text { thereafter annually; annual mammography }\end{array}$ & $\begin{array}{l}\text { Specialist nurse check-up visits if } \\
\text { requested by patient; annual } \\
\text { mammography }\end{array}$ & 131 & 133 & $14(11)$ & $14(11)$ & NR & $0.6^{\mathrm{a}}$ \\
\hline \multirow[t]{2}{*}{$\begin{array}{l}\text { Wattchow et al. } \\
2006\end{array}$} & $\begin{array}{c}\text { Followed by Surgeon; Visits every } 3 \text { months for the } \\
\text { first } 2 \text { years, then every } 6 \text { months for the next } 3 \\
\text { years; faecal occult blood tests every year; } \\
\text { colonoscopy every } 3 \text { years }\end{array}$ & $\begin{array}{l}\text { Followed by GP; Visits every } 3 \\
\text { months for the first } 2 \text { years, then } \\
\text { every } 6 \text { months for the next } 3 \text { years; } \\
\text { faecal occult blood tests every year; } \\
\text { colonoscopy every } 3 \text { years }\end{array}$ & 106 & 97 & $11(10)$ & $8(8)$ & NR & $0.69^{\mathrm{a}}$ \\
\hline & $\begin{array}{l}\text { Carcinoembryonic antigen, CT }=\text { Computed tomogra } \\
\text { n emission tomography, FDG }- \text { flurodeoxyglucose, } \mathrm{L} \\
\text { practitioner , PET = positron emission tomography, } \\
\text { d, NS = Not significant (authors in respective articles } \\
\text { ted by Student's T-test, }{ }^{c} \text { Calculated by Chi squared st }\end{array}$ & $\begin{array}{l}\text { ny, CXR = Chest Radiograph (X-Ray), } \\
\Gamma=\text { liver function tests, US = ultrasono } \\
=\text { Risk Ratio, OR = Odds Ratio, HR = } \\
\text { ted the difference was not significant } \\
\text { istic, }{ }^{\mathrm{d}} \text { Calculated by Cox proportional }\end{array}$ & $\begin{array}{l}\text { id no } \\
\text { rds te }\end{array}$ & e blo & $\begin{array}{l}\text { dence I } \\
{ }^{\text {a Calc }} \\
\text { t, as rep }\end{array}$ & $\begin{array}{l}\text { al, NR } \\
\text { d by li } \\
\text { l by th }\end{array}$ & $\begin{array}{l}\text { y, GP } \\
\text { test } \\
\text { autho }\end{array}$ & \\
\hline
\end{tabular}


More intensive Less intensive

Risk Ratio

Risk Ratio

Events Total Events Total Weight M-H, Random, 95\% Cl M-H, Random, $95 \% \mathrm{Cl}$

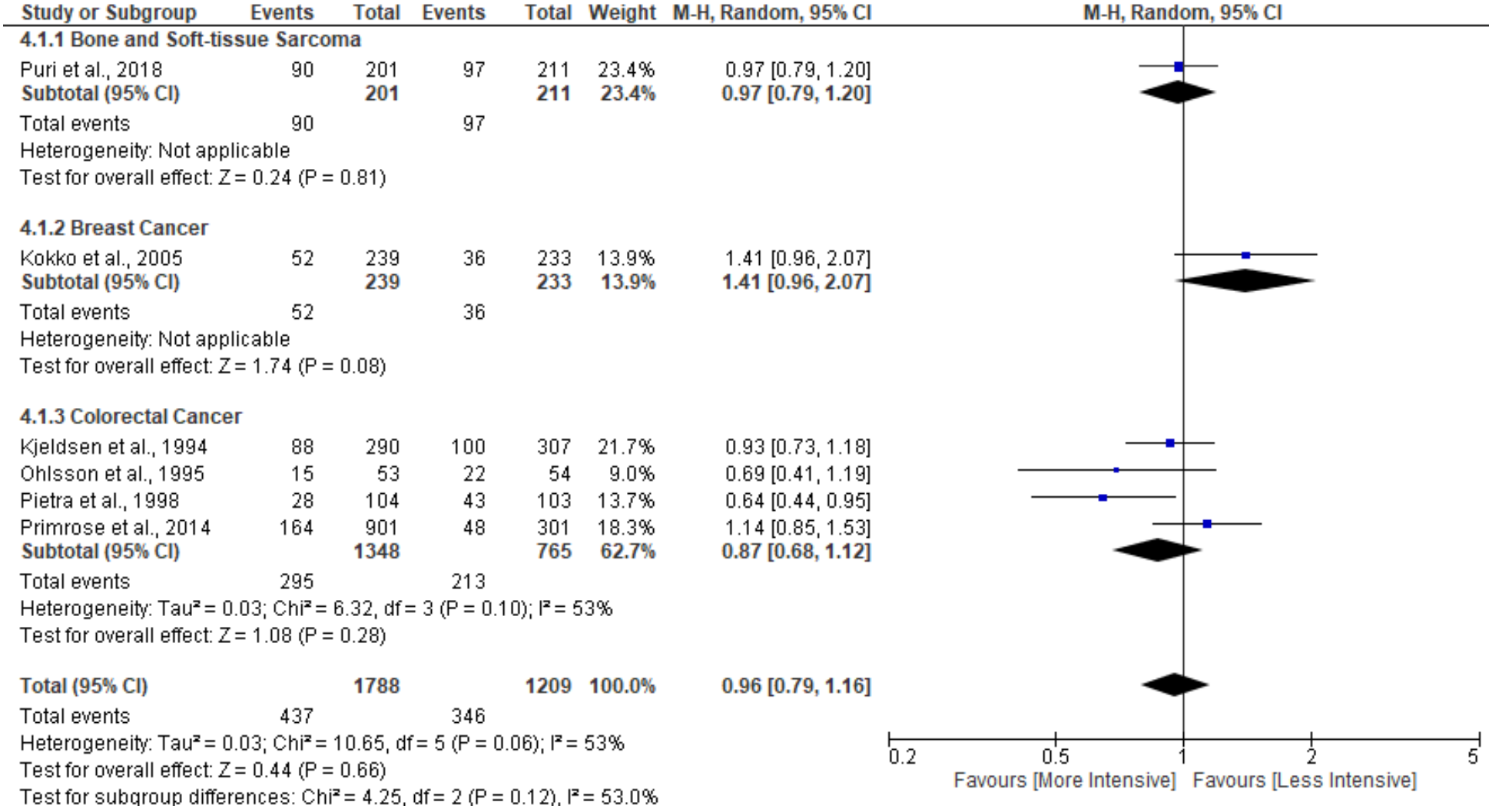

Figure 3: Forest plot of frequency interventions. p-value $<0.05$ is considered significant. 


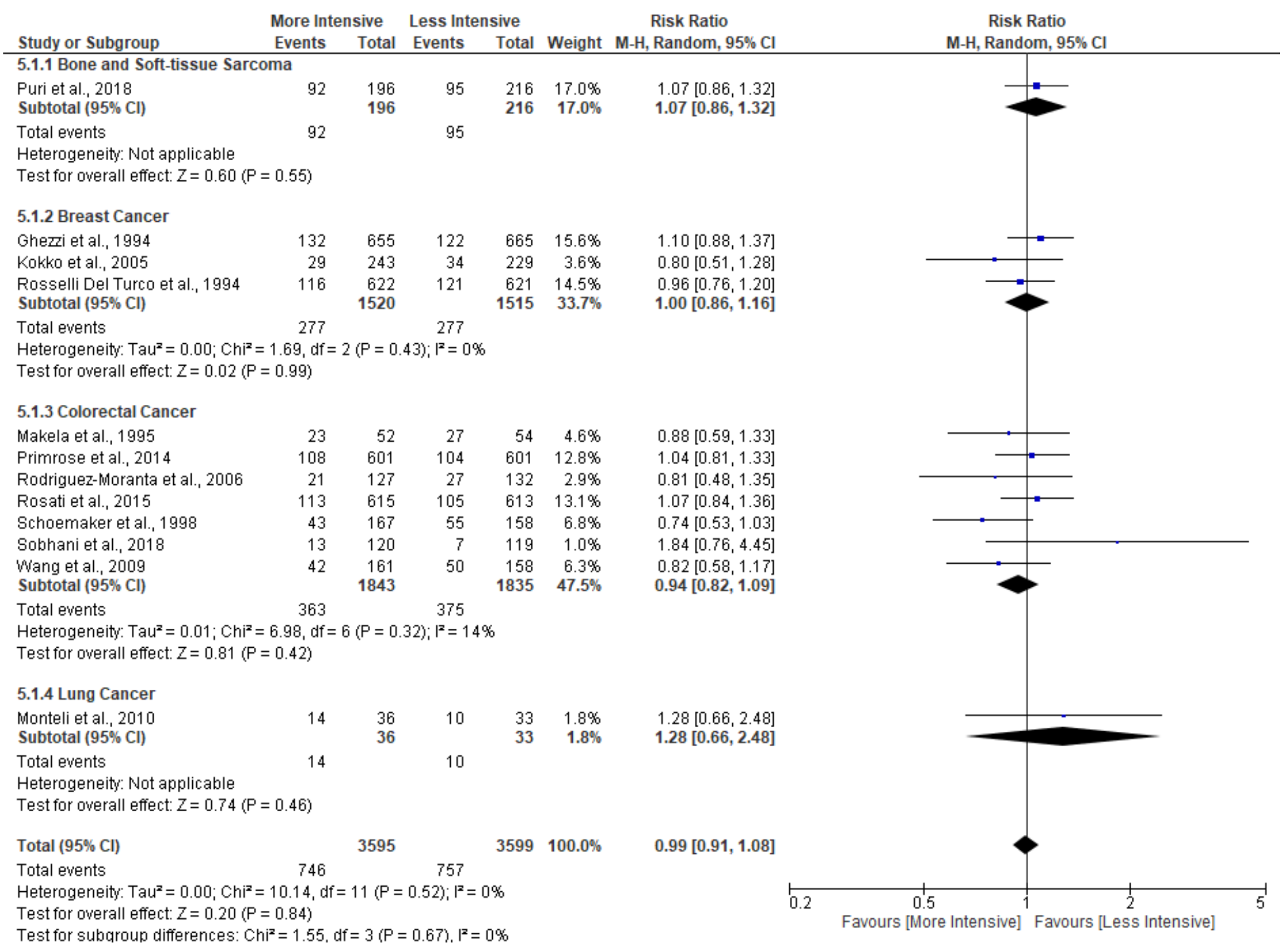

Figure 4: Forest plot of imaging interventions. p-value $<0.05$ is considered significant.

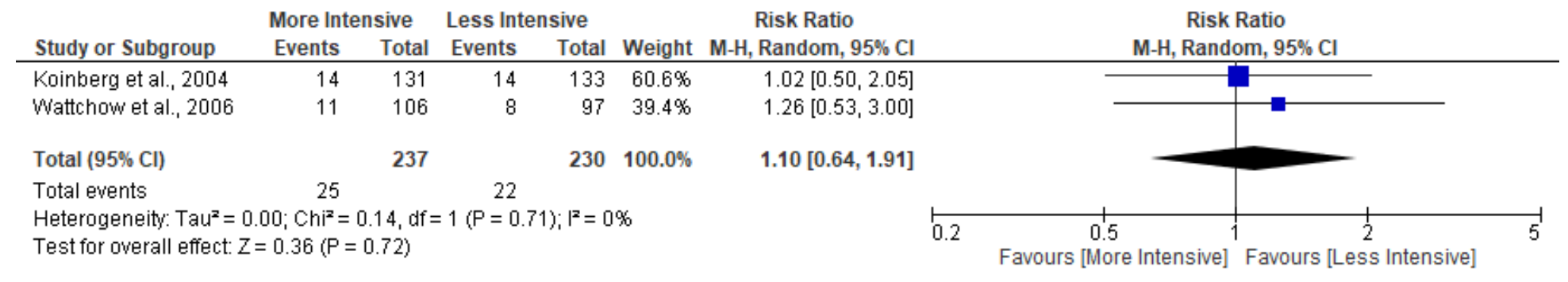

Figure 5: Forest plot of practitioner type interventions. p-value $<0.05$ is considered significant. 
Table 4: Summary of Findings

Summary of findings:

\begin{tabular}{|c|c|c|c|c|c|c|}
\hline \multirow{2}{*}{ Outcomes } & \multicolumn{2}{|c|}{$\begin{array}{l}\text { Anticipated absolute effects" }(95 \% \\
\text { Cl) }\end{array}$} & \multirow{2}{*}{$\begin{array}{l}\text { Relative effect } \\
\quad(95 \% \mathrm{Cl})\end{array}$} & \multirow{2}{*}{$\begin{array}{c}\text { № of participants } \\
\text { (studies) }\end{array}$} & \multirow{2}{*}{$\begin{array}{l}\text { Certainty of the } \\
\text { evidence } \\
\text { (GRADE) }\end{array}$} & \multirow{2}{*}{ Comments } \\
\hline & $\begin{array}{l}\text { Risk with low- } \\
\text { intensity }\end{array}$ & $\begin{array}{l}\text { Risk with high- } \\
\text { intensity }\end{array}$ & & & & \\
\hline \multicolumn{7}{|c|}{ High-intensity biological tests compared to low-intensity biological tests } \\
\hline Deaths (OS) & 180 per 1,000 & $\begin{array}{l}173 \text { per } 1,000 \\
(135 \text { to } 221)\end{array}$ & $\begin{array}{c}\text { RR } 0.96 \\
(0.75 \text { to } 1.23)\end{array}$ & $\begin{array}{c}1202 \\
(1 \mathrm{RCT})\end{array}$ & $\underset{\mathrm{LOW} a \mathrm{a}, \mathrm{b}}{\oplus \oplus \bigcirc \bigcirc}$ & $\begin{array}{l}\text { High-intensity biological tests likely } \\
\text { results in little to no difference in overall } \\
\text { survival. }\end{array}$ \\
\hline \multicolumn{7}{|c|}{ High-frequency compared to low-frequency surveillance } \\
\hline Deaths (OS) & 286 per 1,000 & $\begin{array}{l}275 \text { per } 1,000 \\
(226 \text { to } 332)\end{array}$ & $\begin{array}{c}\text { RR } 0.96 \\
(0.79 \text { to } 1.16)\end{array}$ & $\begin{array}{c}2997 \\
(6 \text { RCTs) }\end{array}$ & $\bigoplus_{\text {MODERATE }} \bigoplus^{\mathrm{a}}$ & $\begin{array}{l}\text { High frequency likely results in little to } \\
\text { no difference in overall survival. }\end{array}$ \\
\hline \multicolumn{7}{|c|}{ High-intensity imaging compared to low-intensity imaging } \\
\hline Deaths (OS) & 210 per 1,000 & $\begin{array}{c}208 \text { per } 1,000 \\
(191 \text { to } 227)\end{array}$ & $\begin{array}{c}\text { RR } 0.99 \\
(0.91 \text { to } 1.08)\end{array}$ & $\begin{array}{c}7194 \\
\text { (11 RCTs) }\end{array}$ & $\underset{\text { MODERATE }}{\bigoplus \bigoplus}$ & $\begin{array}{l}\text { High-intensity imaging likely results in } \\
\text { little to no difference in overall survival. }\end{array}$ \\
\hline \multicolumn{7}{|c|}{ High-intensity practitioner compared to low-intensity practitioner } \\
\hline Deaths (OS) & 96 per 1,000 & $\begin{array}{c}105 \text { per } 1,000 \\
(61 \text { to } 183)\end{array}$ & $\begin{array}{c}\text { RR } 1.10 \\
(0.64 \text { to } 1.91)\end{array}$ & $\begin{array}{l}467 \\
(2 \mathrm{RCTs})\end{array}$ & $\begin{array}{l}\oplus \bigoplus \bigcirc \bigcirc \\
\mathrm{LOW}_{\mathrm{a}, \mathrm{b}}\end{array}$ & $\begin{array}{c}\text { High-intensity practitioner likely results } \\
\text { in little to no difference in overall } \\
\text { survival. }\end{array}$ \\
\hline \multicolumn{7}{|c|}{$\begin{array}{l}\text { *The risk in the intervention group (and its } 95 \% \text { confidence interval) is based on the assumed risk in the comparison group and the relative effect of the } \\
\text { intervention (and its } 95 \% \mathrm{Cl} \text { ). }\end{array}$} \\
\hline Cl: Confidence inter & RR: Risk ratio & & & & & \\
\hline
\end{tabular}

\section{GRADE Working Group grades of evidence}

High certainty: We are very confident that the true effect lies close to that of the estimate of the effect

Moderate certainty: We are moderately confident in the effect estimate: The true effect is likely to be close to the estimate of the effect, but there is a possibility that it is substantially different

Low certainty: Our confidence in the effect estimate is limited: The true effect may be substantially different from the estimate of the effect

Very low certainty: We have very little confidence in the effect estimate: The true effect is likely to be substantially different from the estimate of effect

\section{Explanations}

a. Funnel plots demonstrate probable publication bias

b. $\quad$ Number of included trials and events were low leading to large confidence intervals and possible imprecision in data 


\section{References}

1. Miller KD, Siegel RL, Lin CC, Mariotto AB, Kramer JL, Rowland JH, Stein KD, Alteri R, Jemal A. Cancer treatment and survivorship statistics, 2016. CA Cancer J Clin. 2016;66(4):271-289.

2. Frangioni, J. V. New technologies for human cancer imaging. Journal of clinical oncology. 2008;26(24): 4012.

3. Imyanitov, E., \& Sokolenko, A. Molecular diagnostics in clinical oncology. Frontiers in molecular biosciences. 2018;5, 76.

4. Brenner DJ, Hall EJ. Computed tomography--an increasing source of radiation exposure. $N$ Engl J Med. 2007;357(22):2277-2284.

5. Longo CJ, Deber R, Fitch M, Williams AP, D'Souza D. An examination of cancer patients' monthly "outof-pocket" costs in Ontario, Canada. Eur J Cancer Care (Engl). 2007;16(6):500-507.

6. Goel A, Christy MEL, Virgo KS, Kraybill WG, Johnson FE. Costs of follow-up after potentially curative treatment for extremity soft-tissue sarcoma. Int J Oncol. 2004;25(2):429-435.

7. Thompson CA, Charlson ME, Schenkein E, et al. Surveillance CT scans are a source of anxiety and fear of recurrence in long-term lymphoma survivors. Ann Oncol Off J Eur Soc Med Oncol. 2010;21(11):22622266.

8. Schapira, D. V. Breast cancer surveillance-a cost-effective strategy. Breast cancer research and treatment. 1993;25(2):107-111.

9. Tzeng, C. W. D., Abbott, D. E., Cantor, S. B., Fleming, J. B., Lee, J. E., Pisters, P. W., ... \& Katz, M. H. Frequency and intensity of postoperative surveillance after curative treatment of pancreatic cancer: a costeffectiveness analysis. Annals of surgical oncology. 2013;20(7): 2197-2203.

10. Wu, J. X., Beni, C. E., Zanocco, K. A., Sturgeon, C., \& Yeh, M. W. Cost-effectiveness of long-term every three-year versus annual postoperative surveillance for low-risk papillary thyroid cancer. Thyroid. 2015;25(7): 797-803.

11. Virgo, K. S., Vernava, A. M., Longo, W. E., McKirgan, L. W., \& Johnson, F. E. Cost of patient follow-up after potentially curative colorectal cancer treatment. Jama. 1995;273(23):1837-1841.

12. American Society of Clinical Oncology. Five Things Physicians and Patients Should Question. Choosing Wisely. 2013. Retrieved from: https://www.choosingwisely.org/wp-content/uploads/2015/02/ASCOChoosing-Wisely-List.pdf

13. Miller KD, Nogueira L, Mariotto AB, Rowland JH, Yabroff KR, Alfano CM, Jemal A, Kramer JL, Seigel RL. Cancer treatment and survivorship statistics, 2019. CA Cancer J Clin. 2019;69(5):363-385.

14. National Comprehensive Cancer Network. Development and Update of the NCCN Guidelines. 2020. Retrieved from: https://www.nccn.org/professionals/development.aspx

15. Wright, J. G. A practical guide to assigning levels of evidence. JBJS. 2007;89(5): 1128-1130.

16. Scottish Intercollegiate Guidelines Network. Search Filters. 2019. Retrieved from: https://www.sign.ac.uk/search-filters.html

17. Higgins Julian PT, Altman DG, Gøtzsche PC, Jüni P, Moher D, Oxman AD, Savović J, Schulz KF, Weeks $\mathrm{L}$, Sterne JAC, et al. The Cochrane Collaboration's tool for assessing risk of bias in randomised trials. BMJ. 2011;343:d5928.

18. Schünemann H, Brożek J, Guyatt G, Oxman A, editors. GRADE handbook for grading quality of evidence and strength of recommendations. Updated October 2013. The GRADE Working Group, 2013. Available fromguidelinedevelopment.org/handbook.

19. Deeks, J. J. Issues in the selection of a summary statistic for meta-analysis of clinical trials with binary outcomes. Statistics in medicine. 2002;21(11): 1575-1600

20. Higgins, J. P., Thompson, S. G., Deeks, J. J., \& Altman, D. G. Measuring inconsistency in metaanalyses. Bmj. 2003;327(7414): 557-560.

21. Review Manager (RevMan) [Computer program]. Version 5.3. Copenhagen: The Nordic Cochrane Centre, The Cochrane Collaboration, 2014. 
22. Ghezzi, P., Magnanini, S., Rinaldini, M., Berardi, F., Di Biagio, G., Testare, F., ... \& Fumagalli, M. Impact of follow-up testing on survival and health-related quality of life in breast cancer patients: a multicenter randomized controlled trial. Jama,. 1994;271(20): 1587-1592.

23. Kjeldsen, B. J., Kronborg, O., Fenger, C., \& Jørgensen, O. D. A prospective randomized study of followup after radical surgery for colorectal cancer. British journal of surgery. 1997;84(5): 666-669.

24. Koinberg, I. L., Fridlund, B., Engholm, G. B., \& Holmberg, L. Nurse-led follow-up on demand or by a physician after breast cancer surgery: a randomised study. European Journal of Oncology Nursing. 2004;8(2): 109-117.

25. Kokko, R., Hakama, M., \& Holli, K. Role of chest X-ray in diagnosis of the first breast cancer relapse: a randomized trial. Breast cancer research and treatment. 2003; 81(1): 33-39.

26. Kokko, R., Hakama, M., \& Holli, K. Follow-up cost of breast cancer patients with localized disease after primary treatment: a randomized trial. Breast cancer research and treatment. 2004;93(3): 255-260

27. Mäkelä, J., Laitinen, S., \& Kairaluoma, M. I. Early results of follow-up after radical resection for colorectal cancer. Preliminary results of a prospective randomized trial. Surgical oncology. 1992;1(2): 157-161.

28. Mäkelä, J. T., Laitinen, S. O., \& Kairaluoma, M. I. Five-year follow-up after radical surgery for colorectal cancer: results of a prospective randomized trial. Archives of surgery. 1995;130(10): 1062-1067.

29. Monteil, J., Vergnenègre, A., Bertin, F., Dalmay, F., Gaillard, S., Bonnaud, F., \& Melloni, B. Randomized follow-up study of resected NSCLC patients: conventional versus 18F-DG coincidence imaging. Anticancer research. 2010;30(9): 3811-3816.

30. Ohlsson, B., Breland, U., Ekberg, H., Graffner, H., \& Tranberg, K. G. Follow-up after curative surgery for colorectal carcinoma. Diseases of the colon \& rectum. 1995;38(6): 619-626.

31. Pietra, N., Sarli, L., Costi, R., Ouchemi, C., Grattarola, M., \& Peracchia, A. Role of follow-up in management of local recurrences of colorectal cancer. Diseases of the colon \& rectum. 1998:41(9): 11271133.

32. Primrose, J. N., Perera, R., Gray, A., Rose, P., Fuller, A., Corkhill, A., ... \& Mant, D. Effect of 3 to 5 years of scheduled CEA and CT follow-up to detect recurrence of colorectal cancer: the FACS randomized clinical trial. Jama. 2014;311(3): 263-270.

33. Puri, A., Gulia, A., Hawaldar, R., Ranganathan, P., \& Badwe, R. A. Does intensity of surveillance affect survival after surgery for sarcomas? Results of a randomized noninferiority trial. Clinical Orthopaedics and Related Research®. 2014;472(5): 1568-1575.

34. Puri, A., Ranganathan, P., Gulia, A., Crasto, S., Hawaldar, R., \& Badwe, R. A. Does a less intensive surveillance protocol affect the survival of patients after treatment of a sarcoma of the limb? updated results of the randomized toss study. The bone \& joint journal. 2018;100(2): 262-268.

35. Rodríguez-Moranta, F., Saló, J., Arcusa, À., Boadas, J., Piñol, V., Bessa, X., ... \& Piqué, J. M. Postoperative surveillance in patients with colorectal cancer who have undergone curative resection: a prospective, multicenter, randomized, controlled trial. Journal of Clinical Oncology. 2006;24(3): 386-393.

36. Rosati, G., Ambrosini, G., Barni, S., Andreoni, B., Corradini, G., Luchena, G., ... \& Martignoni, G. A randomized trial of intensive versus minimal surveillance of patients with resected Dukes B2-C colorectal carcinoma. Annals of Oncology. 2016;27(2): 274-280.

37. Rosselli Del Turco, M., Palli, D., Cariddi, A., Ciatto, S., Pacini, P., \& Distante, V. Intensive diagnostic follow-up after treatment of primary breast cancer: a randomized trial. JAMA-Journal of the American Medical Association-US Edition. 1994;271(20): 1593-1597.

38. Schoemaker, D., Black, R., Giles, L., \& Toouli, J. Yearly colonoscopy, liver CT, and chest radiography do not influence 5-year survival of colorectal cancer patients. Gastroenterology. 1998;114(1): 7-14.

39. Secco, G. B., Fardelli, R., Gianquinto, D., Bonfante, P., Baldi, E., Ravera, G., ... \& Ferraris, R. Efficacy and cost of risk-adapted follow-up in patients after colorectal cancer surgery: a prospective, randomized and controlled trial. European journal of surgical oncology. 2002;28(4): 418-423.

40. Sobhani, I., Itti, E., Luciani, A., Baumgaertner, I., Layese, R., André, T., ... \& Taieb, J. Colorectal cancer (CRC) monitoring by 6-monthly 18FDG-PET/CT: an open-label multicentre randomised trial. Annals of Oncology. 2018;29(4): 931-937. 
41. Wang, T., Cui, Y., Huang, W. S., Deng, Y. H., Gong, W., Li, C. J., \& Wang, J. P. The role of postoperative colonoscopic surveillance after radical surgery for colorectal cancer: a prospective, randomized clinical study. Gastrointestinal endoscopy. 2009;69(3): 609-615.

42. Wattchow, D. A., Weller, D. P., Esterman, A., Pilotto, L. S., McGorm, K., Hammett, Z., ... \& Silagy, C. General practice vs surgical-based follow-up for patients with colon cancer: randomised controlled trial. British journal of cancer. 2006;94(8): 1116-1121.

43. Yabroff, K. R., Gansler, T., Wender, R. C., Cullen, K. J., \& Brawley, O. W. Minimizing the burden of cancer in the United States: Goals for a high-performing health care system. CA: a cancer journal for clinicians. 2019;69(3): 166-183.

44. Shulman, L. N., Jacobs, L. A., Greenfield, S., Jones, B., McCabe, M. S., Syrjala, K., ... \& Santacroce, S. Cancer care and cancer survivorship care in the United States: will we be able to care for these patients in the future?. Journal of oncology practice. 2009;5(3): 119-123.

45. Greenberg, D. D., \& Crawford, B.guyya Surveillance strategies for sarcoma: results of a survey of members of the musculoskeletal tumor society. Sarcoma, 2016.

46. Renehan, A. G., Egger, M., Saunders, M. P., \& T O'Dwyer, S. Impact on survival of intensive follow up after curative resection for colorectal cancer: systematic review and meta-analysis of randomised trials. Bmj. 2002;324(7341): 813.

47. Montgomery, D. A., Krupa, K., \& Cooke, T. G. Alternative methods of follow up in breast cancer: a systematic review of the literature. British journal of cancer. 2007;96(11):1625-1632.

48. Bhandari, M., Devereaux, P. J., Montori, V., Cinà, C., Tandan, V., Guyatt, G. H., \& Evidence-Based Surgery Working Group. Users' guide to the surgical literature: how to use a systematic literature review and meta-analysis. Canadian journal of surgery. 2004;47(1): 60.

49. Augestad, K. M., Norum, J., Dehof, S., Aspevik, R., Ringberg, U., Nestvold, T., ... \& Lindsetmo, R. O. Cost-effectiveness and quality of life in surgeon versus general practitioner-organised colon cancer surveillance: a randomised controlled trial. BMJ open. 2013;3(4): e002391.

50. Pita Fernández S, AlhayekAí M, GonzálezMartín C, et al. Intensive follow-up strategies improve outcomes in nonmetastatic colorectal cancer patients after curative surgery: a systematic review and metaanalysis. Ann Oncol. 2015;26:644.

51. Figueredo A, Rumble RB, Maroun J, et al. Follow-up of patients with curatively resected colorectal cancer: a practice guideline. BMC Cancer. 2003;3:26.

52. Jeffery M, Hickey BE, Hider PN. Followup strategies for patients treated for nonmetastatic colorectal cancer. Cochrane Database Syst Rev; 2007.CD002200.

53. Tjandra JJ, Chan MK. Follow-up after curative resection of colorectal cancer: a meta-analysis. Dis Colon rectum. 2007;50:1783

54. Palumbo, M. O., Kavan, P., Miller, W., Panasci, L., Assouline, S., Johnson, N., ... \& Batist, G. Systemic cancer therapy: achievements and challenges that lie ahead. Frontiers in pharmacology. 2013;4, 57. 